\title{
The Modern Reform of the Civil Procedure Law of the People's Republic of China
}

\author{
Gong Nan* \\ East China University of Political Science and Law \\ 1575 Wanghangdu Lu Road, 200042 Shanghai, \\ P.R. China
}

Received 16.05.2016, received in revised form 25.06.2017, accepted 22.08.2017

The introduction of changes in the Chinese Civil Procedure Code (CPC of the PRC) in 2012 and the release of the "Interpretations of the Supreme People's Court of China on the Applicability of Certain Provisions of the CPC of the PRC" in 2014 are significant steps in modernizing the CPC of the PRC, whose goal is to create "just, efficient and authoritative" judicial system. Xi Jinping, the Secretary General of the PRC, put forward the following requirement for the work of the People's courts: "Devote every effort to make people feel justice and truth in every particular case". This is the goal of the struggle and the strategic task of the people's courts, and the aspiration of the entire Chinese nation. The adoption of changes in the CPC of the PRC, as well as the correspondent interpretations of the Supreme People's Court of China and their implementation are of great importance for the correct, uniform, strict and effective implementation of the new edition of the $C P C$, in order to ensure equality of procedural rights, guaranteeing the legality and fairness of justice. These measures also contribute to the economy and society development, the maintenance of harmony and stability in the society, the more resolute construction of the socialist system of law and order with Chinese specifics and of the socialist legal state, creating the court positive image and enhancing the judiciary power authority.

Keywords: reform, civil process, China.

Supported by Foundation of The China Institute for SCO International Exchange and Judicial Cooperation (CNSCO17035) and Supported by Excellent Youth Foundation of The Heilongjiang university (QW201621)

DOI: 10.17516/1997-1370-0166.

Research area: law.

The current Civil Procedure Code of the People's Republic of China (hereinafter referred to as the CPC of the PRC) was adopted in 1991 at the $4^{\text {th }}$ session of the $7^{\text {th }}$ National People's Congress of the parliamentary representatives, with the last amendment made in accordance with the Decision "On Amending the Civil Procedure Code of the People's Republic of China" of August 31, 2012, signed at the $28^{\text {th }}$ meeting of the Standing Committee of the $11^{\text {th }}$ National People's Congress. ${ }^{1}$ In December 2014, the Supreme Court of the People's Republic of

(C) Siberian Federal University. All rights reserved

* Corresponding author E-mail address: gong525@163.com 
China adopted the "Interpretations of the Civil Procedure Code" (Interpretations of the CPC), the most significant in terms of the volume and number of articles among similar acts. 23 chapters of the CPC Interpretations have 552 articles. In the Chinese legal system, in addition to laws, there are other sources that are adopted by higher authorities. These can be the General Prosecutor's Office of the PRC, Ministries and the Supreme Court of the PRC. In the acts of the latter, the meaning of the norms of substantive and procedural law is clarified, which enables unifying the law enforcement and improving the judicial process as well.

Thus, the "Interpretations of the CPC" give comprehensive, systematic and specific explanations on the application of certain provisions of the CPC of the PRC in the People's courts. After their adoption, the mechanisms of civil litigation and conflict resolution were revised and supplemented in terms of fundamental principles and specific systems. This was the most important achievement of the civil process reform in China.

The editorial board of the CPC and the "Interpretations of the CPC", first of all, made it possible to improve the interaction between mediation and judicial proceedings. The role of mediation was brought forward, as mediation is an effective way of timely resolution of disputes between citizens at the place where disputes occurred. Novels improved the process of presenting claims, taking the case to consideration, and providing evidence and proof. As a result, the national interest in the judiciary increased, as it allowed to ensure the rights of the parties substantially and to redistribute judicial resources in a more rational way.

It should be noted that the reform has strengthened the supremacy of law, the authority of the judiciary system, which has become more effective. It is also important that the updated judicial system is an essential component of the Chinese socialist legal system, one of the guarantees for the implementation of the "Chinese dream" about the Chinese nation's revival. Let us now consider a number of critical elements of the civil process reform. ${ }^{2}$

\section{Determination of the Principle of Bona Fides}

During the work on the new edition of the CPC in 2012, a number of departments and scientists proposed to introduce the principle of bona fides (conscientiousness) into its text. This proposal was approved by the legislature, and was adopted unanimously. Now Paragraph 1 Article 13 of the CPC says: "In the civil process, the principle of bona fides must be observed".

\subsection{The Core of the Principle of Bona Fides}

The principle of bona fides is also called the "regal principle" of modern civil legislation. It obliges the subjects of the market economy to act in a spirit of honesty, to observe the principle of the highest trust, to fulfill their promises. The principle of bona fides is a requirement forbidding taking advantage of one's actions if they violate the interests of other actors or the public interest. Thus, the principle of bona fides legitimizes moral norms.

The category of "bona fides" dates back to Roman law and was originally understood in the context of a conscientious agreement that gradually expanded to a general principle, the effect of which embraced the full range of civil law relations. The policy of legal reforms, conducted in the PRC, applied conscientiousness to the sphere of private law. Article 4 of the CPC of the PRC establishes a general provision that the activities of participants in civil relations should be based on the principles of voluntariness, justice, equivalent remuneration, honesty and trust. These provisions correlate with the norm of 
Article 6, which requires the subjects to use their rights and obligations to adhere to bona fides. The last principle was transferred to the procedure law from the provisions of substantive law.

The principle of bona fides in the CPC is derived from the principle of a conscientious claim in Roman law. The court, parties and other participants are obliged to make claims guided by the principles of justice, honesty and kindness. The report at the $18^{\text {th }}$ All-China Congress of the Communist Party Central Committee formulated specific details of bona fides principle for all spheres of legal life. In particular, it named strengthening of administrative conscientiousness, trustworthiness in commercial activity, good faith in regulation of public relations and increase in public trust to justice. The Decisions of the $4^{\text {th }}$ Plenum of the $18^{\text {th }}$ Communist Party Central Committee Meeting indicated the need to strengthen the society conscientiousness, to update the system of lending to citizens and organizations, to improve mechanisms for encouraging the law enforcement, as well as to modernize the system of punishment for unlawful behavior. Therefore, bona fides took a worthy place in the list. Eventually, apart from the definition of bona fides in the General Part of the CPC, its Special Part also contained provisions on the prohibition of false claims, evasion of execution, increasing the upper limit of the fine for violation of civil procedural rules.

\subsection{The Need to Define the Principle of Bona Fides in the CPC}

The consolidation of the bona fides principle in the CPC was the answer to the existing judicial practice. Since the adoption of the Civil Procedure Code in 1991 the civil process has been rapidly developing. On the one hand, this has made it possible to achieve significant progress in reforming the adversarial procedural form of legal proceedings. On the other hand, the unfair behaviour of participants in a civil dispute has become more often, which has threatened the implementation of judicial functions.

\subsubsection{Reforming the judicial order determines the coordination model of the adversarial civil process}

Until the 1980s the civil process had remained an investigative process. The activity of the judges was emphasized, as they played the main role in the case decision. The main task of legal proceedings was the investigation of the case by a judge, who fulfilled the duty to disclose the true facts. The rights of the parties in the process of proof were diminished. As a result, the civil process was far from efficient.

The rapid development of market relations after the 1980s led to a significant increase in civil cases in the courts, all the shortcomings of the then existing civil process model worsened, which forced lawyers to intensify the search for ways to reform the model of civil proceedings in theory and practice. The solution was seen in the transition from the powerful investigative model to the coordination model. In this case, the civil process parties were given leadership, and their procedural rights were broadened. The party now bears the burden of proof, the court is no longer obliged to search for evidence, and more attention is paid to procedural competition. All these achievements were specified in the CPC of 1991.

The results are as follows: the coordination model has increased the status of parties in the civil process; the court is to respect the results of dispositional actions of the parties; the court decision now largely depends on the ability of the parties to provide true evidence. It should be noted that simultaneously with positive results there appears the risk that the parties may abuse the procedural rights granted to them. Historically it has been proved that adversariality 
should not be absolute, it requires restriction, and the principle of bona fides can help here. It provides an opportunity to observe the balance of rights and responsibilities, to ensure the normal course of the civil process, and to achieve justice and efficiency of court decisions.

\subsubsection{There are problems connected} to procedural norms violation, which seriously affects the process fairness and efficiency, leading to fall

in public confidence in justice

One of the most important problems of the civil process is the parties' abuse of the right to claim, which is mainly manifested in false claims. It means that parties present fictitious facts, deliberately mislead the court, and seek to make the court decide in their favor. This manifests itself in a malicious collusion between the parties, imitating civil-law relations, the falsification of facts in order to achieve a false agreement with a view to concluding a settlement agreement. Through malicious collusion and false confessions, the parties get judicial decisions that damage others. There has been an increase in cases of fictitious divorce, cases of transferring property to other persons in order to avoid its confiscation for debts. In cases of divorce, one of the spouses declares false debts in order to cause damage to the other spouse. In general, abuse of procedural rights can be exercised with the aim of preventing the consideration of the case, attacking the rights and legitimate interests of the opposing party and influencing the normal course of the proceedings. This apparently happens in such cases: the abuse of the right to justiciability, the application for judge disqualification, the delivery of documents, reconciliation, appeal, revision, protest and dishonesty during the production of proof. A grave problem is the evading the execution of judicial decisions.
So, some parties, although they have the ability to repay the debt, do not fulfill their duty deliberately. ${ }^{3}$ For example, they transfer property to another person and thereby hide it from execution.

Serious problems of the parties' dishonesty as regards the civil process once again confirmed the need for the bona fides principle as the fundamental basis of civil procedural law. There was a need to duly punish the above-mentioned actions with a view to promoting the bona fides principle; in this connection, the "Clarifications of the Supreme People's Court of China on the application of certain provisions of the CPC of the PRC" gives additional provisions:

1) provision for compensation for violations of the bona fides principle, penalty for the false personation, for giving false testimony and other similar actions;

2) a number of provisions aimed at encouraging discipline among the process participants, which would contribute to respect for the court and procedural opponents. The application of a general rule on the refusal to take evidence after the time limit must force the parties to abandon the idea of delaying the process by tendering evidence;

3) provision stipulating the legal effect of the refusal to sign a written commitment by the parties, in the absence of other evidence on the fact to be proved. In such a situation, the People's Court has not to avow the facts presented. Witnesses who refuse to sign a commitment are not allowed to testify, and take on the corresponding responsibility;

4) system of enlisting the trustless debtors. In the event of the debtor's failure to fulfill the duty, confirmed in legal acts, the People's Court is obliged to collect the amount of debt from the debtor, and on the basis of the circumstances, to include the debtor in the list of trustless debtors, to provide detailed information on the failure or 
incomplete performance of obligations for the debtor's employer, the credit history information service and other bodies it may concern.

\subsection{Application of the Bona Fides Principle}

The scope of the subjects of this principle application: court, parties, other participants in the proceedings (including third parties).

\subsubsection{Bona fides protection}

Articles 112 and 113 of the CPC specifically define compulsory measures against fraud in civil and law enforcement proceedings. For unscrupulous subjects these can be fine, arrest and even criminal liability. These measures perform a preventive function, intimidating the parties planning malicious acts. As a result, the normal order of legal proceedings is ensured, and the successful administration of justice as well as the execution of judicial decisions are guaranteed. Thus, Article 112 obliges the People's Court to dismiss a claim, and, depending on the severity of the circumstances, to impose a fine or arrest the parties who have entered into deliberate conspiracy to encroach on the rights and legitimate interests of third parties. In the case of the commission of acts constituting the offense, these individuals are criminally liable. Article 113 compels the People's Court, depending on the gravity of the circumstances, to fine or arrest the debtor (the person whose property is impounded), who entered into an intentional collusion with another person in order to avoid fulfilling the duties prescribed by the legal act. In the case of the commission of acts constituting the offense, these individuals are criminally liable.

\subsubsection{Application \\ of the bona fides principle by court}

In the CPC there are many resolutions on free discretion. Thus, the judge during the proceedings must act with reasonable discretion in the administration of justice. Judges shall exercise their powers reasonably, for example, while distributing the burden of proof, determining reasonable terms and in other cases. In the case of decisions with free discretion, and when there are no specific definitions in the CPC and "Interpretations", the direct application of the bona fides principle is permissible.

\section{On the Standardization of the Checking Procedure and Use of Evidence}

The system of evidence is the foundation of civil procedural institutions. A serious problem has become the abuse of process rights granted to the parties. Since it is allowed to present new evidence at any time, it can seriously delay the time required to consider the claim, and entail "Litigation Surprise". In the pre-reform period, the following problems emerged: new types of evidence (electronic evidence) claimed by practice, were not recognized; the parties did not have sufficient opportunities to prove their position; there were no effective obstacles to the expert's evasion from participating in the process (not attendance on the summons of the People's Court). As a result, the judicial justice suffered, as well as the principle of access to justice. In this regard, the clarification of the CPC has established measures aimed at resolving the aforementioned problems.

According to Article 65 of the CPC, the parties are obliged to provide evidence in a timely manner in support of their claims. The People's Court determines the list of evidence at the preparation stage for the proceedings, which the parties are required to submit, and the time limits for their submission taking into account the requirements of the parties and the circumstances of the case. If there are confirmed 
difficulties in presenting the evidence within the specified period, the party has the right to apply to the People's Court for an extension. The People's Court, on the basis of the request of the party, extends the period accordingly. In the event that the evidence was submitted with violation of the time limit, the People's Court should oblige the party to submit written explanations. In case of refusal to submit written explanations or insolvency of the arguments in the explanation, the People's Court depending on the circumstances may refuse to attach evidence to the case or attach the evidence to the case with the expression of censure or imposition of a fine. ${ }^{4}$

The expert must appear in the court to apply special knowledge to the facts presented to them and give their opinion. If an expert refuses to appear for testimony on the summons of the People's Court, the expert's opinion cannot be recognized as the basis for confirming the facts in the case, and the parties that paid for the examination costs are entitled to demand the return of the paid expenses. A party has the right to apply to the People's Court with a request to call on persons with professional knowledge who are entitled to give explanations on the issues requiring special qualification and to ask questions to the expert to present opinion on professional issues or on the opinion of the expert.

Now new types of evidence are being developed, electronic evidence among them. They are currently included in the list of permissible evidence, which is given in the CPC. This is predetermined by scientific and technical development, the development of new ways of recording, transferring and storing information.

Thus, in some cases, courts are forced to evaluate electronic evidence (for example, electronic documents), which are often crucial for the proper resolution of a civil dispute.

\section{Statements about Further Improvement of Procedural Discipline}

The Decisions of the $4^{\text {th }}$ Plenum of the $18^{\text {th }}$ Communist Party Central Committee Meeting note the need to improve the penal system for perverting the course of justice, for failure to comply with judicial rulings and decisions, for neglecting the principle of the rule of the court and other unlawful acts. Recent years have been marked by the rapid development of information technology. The participants of the process have acquired the opportunity, while in the process, to make video or audio recordings, photographs of the court session without the permission of the court; send information from the courtroom via e-mail, blogs, via WeChat, etc.

Cases of violating the established order in the courtroom, both by the participants of the process, and by other persons present in the court, which took advantage of the openness of the process, have become more frequent. The violation of the order in the courtroom is understood as actions that obstruct judicial proceedings, or demonstrate contempt of the court, or violate the established rules of the court session - noise, screaming, wrangling with the judge, state prosecutor and other participants of the process, intervention from the place, comments, appeal to the court while sitting, without the corresponding permission, non-observance of the rules of etiquette, etc. These problems were brought into the public eye. The "Interpretations" provide for a number of measures applied against violators of order in the court session: the following types of violations of the procedure of the trial sessions by the participants in the process or listeners: recording, recording and shooting without permission of the court; broadcast from the courtroom by mobile communication and using other technical means without permission of the court; other actions that violate the order of the court session and prevent judicial proceedings. 
The "Interpretations" include a number of measures to be applied to violators of the order at the court session: the following types of violating the order at court sessions by the participants of the process or listeners are identified: recording, video recording and shooting without permission of the court; broadcast from the courtroom using mobile communications and other technical means without permission of the court; other actions that violate the order of the court session and impede judicial proceedings.

In accordance with the provisions of Article 110 of the CPC, the People's Court can censure, remove from the courtroom, fine or arrest persons who violate the rules of the court session, and also temporarily withdraw the equipment used to record, shoot and broadcast, to delete the records. In case of refusal, the records are deleted, for which the People's Court may apply compulsory measures. The "Interpretations to the CPC" provide for the removal of violators of the order of court session from the courtroom by the decision of the collegial staff of the court or by the judge alone. The facts of violations should be entered into the records.

\section{Guarantee of the Right to Claim: the Supreme Goal of Reforming Civil Proceedings}

Filing a suit to the court is an important way and means of participation of the parties in civil proceedings and ensuring civil rights. The right to claim is one of the basic constitutional rights of the people. Enforcement and respect for the right to claim is the goal of the legislation, and one of the main requirements to the national courts. "Interpretations" focusing on the protection of the right to claim, in order to effectively implement the standards of the CPC, cover in more detail such issues as appealing to the people's courts with suits for protection of public interests, appealing against court judgments that violate the rights and interests of third parties, proof system, service of judicial documents, preparation for the court session, the judicial review, review of judicial acts, legal enforcement, etc. This demonstrates respect for the right to claim, and defends the dominant role of parties in action proceedings.

\subsection{Ensuring the Implementation of the Concept of Justice in Civil Proceedings - the Main Topic of the "Interpretations" to the CPC}

The Decisions of the $4^{\text {th }}$ Plenum of the $18^{\text {th }}$ Communist Party Central Committee Meeting note that "justice is the core of the rule of law. Judicial justice plays an important leading role in relation to public justice, while judicial injustice plays a deadly destructive role". To implement the spirit of the Decisions of the $4^{\text {th }}$ Plenum of the $18^{\text {th }}$ Communist Party Central Committee Meeting and the demands of President Xi Jinping "to make efforts to ensure that the masses in every matter feel justice and rightness", all 552 articles of this document directly or indirectly specify certain measures to ensure procedural fairness. Moreover, when developing the interpretations of the Supreme People's Court of China on the applicability of certain provisions of the CPC of the PRC, the principle of equality of procedural rights of the parties was emphasized, the necessity of justice, effectiveness and importance of the principle of publicity of justice was outlined; the factor of convenience for the parties of the trial and for the court was implemented, as well as other principles. As a result, the system of civil suits has become more focused on the legal doctrine, which strengthened its functionality.

The right to claim is the basic right for initiation of a civil procedure and the motion of a suit, this is one of the forms of the right for 
judicial protection enshrined in the Constitution of the PRC. Respecting and securing the right to claim is the essence of legislation and the main function of the CPC of the PRC, as well as the basic requirement to people's courts in civil proceedings. The Decisions of the $4^{\text {th }}$ Plenum of the $18^{\text {th }}$ Communist Party Central Committee Meeting indicate the need to strengthen legal guarantees of human rights; the need to strengthen the system of guarantees of the right to inform the parties and other participants of the judicial process, the right to speak, the right to debate, the right to file a statement of claim and the right to appeal. All of them are supposed to guarantee the reality of the basic right: the right to claim.

To implement the new edition of the CPC, the "Interpretations" prescribe the development of a system for registering cases. According to the "Interpretations" the People's Court should register the suit when accepting a written statement of claim, if its content and form correspond to the following requirements: the plaintiff is a citizen, legal entity or other organization having a direct interest in the present case; there is a certain defendant, there are specific claims, facts and arguments; the lawsuit can be applied to the people's court in the civil procedure and can be judged by the people's court, to which the suit is filed (Article 119 of the CPC). If the judge cannot immediately determine the basis for the implementation of the right to claim, they should accept the claim documents and issue a supporting document indicating the date of receipt. If it is necessary to provide additional materials, the court should notify the applicant in a timely manner. After the provision of all necessary documents, the judge within seven days from the date of receipt of the statement of claim is obliged to consider the issue of accepting it.

\subsection{Additional Procedure}

for Judicial Approval

of the Settlement Agreement

The mediation procedure is performed during the trial process, another name for the procedure of approving a settlement agreement as new special proceedings is the Alternative Dispute Resolution (ADR) or voluntary proceedings. With such a model, equity can no longer be equated with justice. ADR as a new channel for ensuring equity, has been rapidly developing and provides citizens with a more convenient and flexible way to resolve disputes. The People's court, if necessary, has the authority to conduct a judicial review of the decision basing on the ADR system. The new edition of the CPC includes the procedure for judicial approval of a settlement agreement, which is the ADR legitimization, and marks the onset of a new stage of reform in the context of combining judicial and non-judicial mechanisms for resolving disputes.

According to Article 194 of the new edition of the CPC of the PRC, the parties can now apply to the court with a request to approve the agreement reached during the course of the mediation within 30 days from the date of its conclusion. If the agreement does not contradict the law, the court issues a consent decree. After the approval by the court, the agreement becomes "a kind of a judicial act" and is subject to compulsory execution. Article 195 of the CPC of the PRC states: "The text of the settlement agreement is presented to the People's court, which gets acquainted with it and gives an assessment on its legitimacy. If, after the approval of a settlement agreement, one of the parties evades its implementation, or does not fully implement it, the other party may apply to the People's court with a claim for its enforcement. If the settlement agreement contradicts the law, the court issues a ruling on the refusal to approve the settlement agreement. The parties have the right, by mediation, to amend 
the previous settlement agreement or to reach a new settlement agreement, and may also file a claim to the People's court". In the new edition of the CPC of the PRC in the chapter "Special Procedures" a rule was added that defines the legal force of the settlement agreement. If one of the parties deviates from the implementation of the settlement agreement not approved by the court, the other party cannot apply to the People's court with a claim for its execution, in this case the party can only file a statement of claim. Here, attention should be paid to the following: 1) mediation is conducted by members of the committees of people's mediation; 2) the application for approval is signed by both parties; 3) the application must be submitted within 30 days after the entry into force of the settlement agreement; 4) one should apply to the lower court of the People's court at the seat of the People's Mediation Committee.

\subsection{On Modernization \\ of Judicial Proceedings in Case \\ of Suits Aimed at the Protection \\ of Public Interests}

The new edition of the CPC of the PRC includes procedural innovations regarding the system of judicial proceedings on public claims - article 55 of the CPC of the PRC: "Institutions and relevant organizations can file a claim to the People's court in relation to actions associated with environmental pollution, an attempt on the legitimate rights and interests of numerous consumers and other actions harmful to the public interest".

With a view to the orderly operation of the court system on public claims, the "Interpretations to the CPC" in accordance with the intent of the legislator and taking into account judicial practice, contain the following provisions:

1) claims in defense of the public interest, in addition to compliance with Article 55 of the
CPC of the PRC, also should comply with certain additional conditions. Among them, the presence of a particular defendant; availability of specific lawsuit requirements; availability of preliminary evidence of causing harm to public interests. The claim should be prepared taking into account the requirements for claims submitted under the civil procedure;

2) it is stated that claims are subject to the jurisdiction of intermediate People's courts at the place where the action was completed or at the defendant's location, unless otherwise provided by law and its interpretation. In the event of pollution of the marine environment, claims are subject to the jurisdiction of the maritime court at the place where the harm was caused, or at the place where pollution prevention measures are applied. With respect to the same legal violations, claims for which have been filed to two or more People's courts, the case is subject to the jurisdiction of the court that first took the claim for consideration, if necessary, the jurisdiction over identical claims is determined by a higher People's court;

3) after adopting the claim for review the people's court is obliged within 10 days to notify in writing the relevant interested administrative competent authorities;

4) the provision on filing a claim in defense of public interests by other bodies and interested organizations involved in the process is specified. After the court has accepted the claim for consideration, these bodies and organizations are obliged to file an application for participation in the suit before the court session. If they are given a judicial authorization to participate in a lawsuit, they are in the position of co-plaintiff;

5) the claims in defense of public interests and personal interest are coordinated between each other. The "Interpretations" indicate that the adoption of a claim in defense of public interests by the court is not an obstacle for the same victim 
to file a claim in relation to the same offense (Article 119 of the CPC of the PRC 5 );

6) the parties can settle the dispute in defense of public interests by concluding a settlement agreement. However, after concluding such an agreement, the People's court should disclose the contents of this agreement in the period of not less than 30 days. At the end of this period, the People's court should verify whether the given settlement agreement violates public interests and, in the absence of such violations, issue a verified written approval to the parties. If there is a violation, the court refuses to issue a written approval, and the decision is made after the trial;

7) there is a restriction on filing an application on the waiver the plaintiff of the claim on public interests protection. After the end of the trial, the people's court does not accept applications for a waiver;

8) if after the court decision enters into force, other bodies and interested organizations having the status of a plaintiff in an identical legal procedure file a separate claim, the People's court should issue a ruling on the refusal to accept the case for consideration if the Law and the "Interpretations" do not provide otherwise.

\section{Additional Statement on Applying to People's Courts for Rehearing of Court Judgements Violating the Rights and Interests of the Third Parties \\ (Hereinafter "Application \\ for the Reversal of a Judgement")}

\subsection{Legislative Framework}

In recent years, cases of false claims, as well as agreements of the parties with the purpose of causing malicious damage to the legitimate rights and interests of the third party, have become more frequent in judicial practice. In this case, the efficiency of legal remedies is diminished, which violates the principle of the validity of law.
In the civil process, it is necessary to ensure the rights of all participants, and not only the parties. In this regard, the key aspect of the new edition of the CPC concerns improving the protection of rights of third parties.

Legal protection of the rights of third parties is mainly provided for in Article 227 of the CPC. If during the execution of a judicial act a person who has not participated in the case makes a written protest regarding the subject of execution, the People's court is obliged to make an inspection within fifteen days from the date of such an appeal. If the arguments are considered plausible, the People's court shall make an order to terminate the enforcement proceedings against the controversial subject matter; if the arguments are unreasonable, an order on the rejection of the protest is made. Such an order may be appealed by an interested person under the rules of reconsideration in the order of national proceedings. If the objection is not related to an earlier decision or ruling, these parties may file a suit to the People's court within fifteen days from the date of delivery of the ruling (Article 227 of the CPC of the PRC).

In the above statement, there are the following disadvantages: firstly, the prerequisite for objection in relation to the object of execution and the appeal of the order is carried out according to the rules of reconsideration and enters the enforcement proceedings. However, in the event that the third party was harmed by the results of the claim - the decision approved or pronounced or a judgment formed on the case - the execution is not required. Even if the procedure of execution has not yet come into effect, the third party cannot obtain effective legal remedies through the above-mentioned channels of legal protection. Secondly, these procedures can effectively protect the violated property right. It happens that the court decision that came into force did not inflict direct damage 
to the property right of the third person, but there were violations of the obligation or other civil law or interest ${ }^{6}$. For example, the parties in a malicious collusion filed a lawsuit to dispose of the property of the debtor, as a result of which the debtor lost some of the property, which did not allow them current debt to the third party. In this case, the above-mentioned legal remedies become deprived of targeting. In the view of the above circumstances, Article 56, Paragraph 3 of the new $\mathrm{CPC}$ of the PRC includes an additional provision on the cancellation of a suit that violates the rights and legitimate interests of the third party.

\subsection{Conditions of Taking Jurisdiction on a Case}

A third person, on the basis of new circumstances, brings an action for the reversal of judgements in order to avoid undue influence on the original decision. These legal actions, in comparison with the usual new lawsuits, should be checked more carefully and, at least, meet the following conditions.

Subjects of legal actions are limited to the third party. The lawsuit on the reversal of the court's decision is a new legal action on the cancellation of the court decision that entered into legal force. Its purpose is to cancel those initial decisions that damage the legitimate rights and interests of the third person. In this regard, when the third person brings this action, the subjects are called the rejected claimant and the respondent, and the court renders the decision on the case without the right of appeal.

Such an action is considered justified if the third person has grounds to believe that some part of the primary decision or the entire decision harms their rights and legitimate interests. In this case, the judgement under attack creates obstacles to the exercise of the rights and legitimate interests of the third party, and the third party has an exceptional interest in this case and cannot resolve the matter through another court case.

Article 227, Paragraph 3 of the CPC provides that the action is brought within six months from the date on which the third party became aware of or should have become aware of the violation of their civil rights and legitimate interests. The third party should provide evidence, proof of the starting point when "it became known or should have become known".

The third party submits the application for consideration to the People's Court, clearly identifies the issues that need to be resolved and sets out the request for the cancelation of certain parts of the judgment or the entire judgement in order to protect their legitimate rights and interests from the damage caused by the entry into force of the court decision.

Paragraph 3 Article 2 of the CPC of the PRC states that the third person should file a suit to the People's court that passed the relevant act, i.e. to the People's court of the first or second instance that took the final decision.

\subsection{Consideration of the Action \\ on the Reversal of Judgements}

When handling the suites for appealing against court decisions violating the rights and interests of the third parties, if the claims are recognized as valid, the People's court should change or cancel the earlier decision, order or settlement agreement. The changed or canceled part in the previously adopted decision loses its legal effect; if the claims are considered invalid, the People's court refuses to answer the claim.

\section{Conclusion}

Amendments to the Civil Procedure Code of the PRC of 2012 and "Interpretations of the Supreme People's Court of China on the Application of Certain Provisions of the CPC of the PRC" of 2014 represent another effort to 
modernize China's civil procedure law. The reform of the CPC corresponds to the trends in the internationalization of the civil process. Its key position is the constitutionalization of the right to claim, which specifies the theory of "access to justice". In order to more effectively ensure "the right of citizens for the access to justice", the future judicial reform should be aimed at closer systematization and coordination of the structure of civil proceedings. The definition of "ensuring the right to claim" as the supreme goal of the CPC of the PRC is a necessary basis for improving legislation, as well as the most urgent task of impartial justice.

1 Decision "On Amending the Civil Procedure Law of the PRC" of August 31, 2012, which came into force on January 1, 2013.

2 Liu Zhiwei (2015). Sistematism application of judicial interpretation of the People's Republic China civil procedure law, In China Law Review, (1).

3 Du Wanhua (2015). The analysis of key points of judicial interpretation of the People's Republic China civil procedure law, In Journal of Law Application, (4).

4 Chang Jie (2016). Improve and perfect losing rights to provide evidence of civil procedure in China, In China Law Review, (1).

5 Article 119 of the CPC. When filing a suit, the following requirements should be met: (1) the plaintiff is a citizen, legal entity or other organization with a direct interest in the case, (2) there is a certain defendant, (3) there are specific claims, facts and arguments, (4) the claim refers to the People's Court to be considered in accordance with civil proceedings and is subject to the jurisdiction of the People's Court to which the suit is filed.

6 Sun Ruirui (2015). Public interest civil litigation in Civil procedure law and judicial interpretation in China, In Legality Vision, (22).

\title{
Современная реформа
}

\section{гражданского процессуального законодательства КНР}

\author{
Гун Нань \\ Хэйлунизянский университет \\ КНР, провиниия Хэйлунизян, 150080 , \\ Харбин, район Нань Ган, ул. Сюе Фу, 74
}

Внесение изменений в Гражданский проиессуальный кодекс КНР (ГПК КНР) в 2012 г. и выпуск «Разъяснений Верховного народного суда КНР о применении отдельных положений ГПК КНР» в 2014 г. является значительным шагом в деле модернизачии ГПК КНР, цель которой заключается в создании «справедливой, эффективной, авторитетной» судебной системы. Генеральный секретарь КНР Си Цзиньпин выдвинул следующее требование к работе народных судов: «Приложить все усилия, чтобы люди почувствовали в каждом конкретном деле справедливость и правду». Это иель борьбы и стратегическая задача работы народных судов, а также чаяние всего китайского народа. Принятие изменений в ГПК КНР, а также разъяснений Верховного народного суда КНР и их реализация имеет большое значение для правильной, единообразной, строгой и эффективной реализачии новой редакции ГПК, для обеспечения равенства процессуальных прав, гарантии законности и справедливости правосудия. Эти меры также способствуют развитию экономики и общества, обеспечению гармонии и стабильности в обществе, более решительному построению сочиалистической системы правопорядка с китайской спецификой и социалистического правового государства, формированию положительного имиджа суда и повышению авторитета судебной власти.

Ключевые слова: реформа, гражданский прочесс, Китай. 
Статья опубликована при поддержке Фонда Китайского института международного обмена и судебного сотрудничества ШОС (CNSCO17035) и при поддержке Превосходного молодежного фонда Университета Хэйлунизян (QW201621)

Научная специальность: 12.00.00 - юридические науки. 